\title{
SEBAHAT DENIZ*
}

\section{Kadızâde Mehmed ilmî'nin Sultan IV. Murad İçin Yazdığı Manzum Duânâme'si}

\author{
Kadızâde Mehmed İlmî's "Duânâme" in Verse for \\ Sultan Murad IV
}

Ö Z E T

Türk kültür ve edebiyatında dua konusunun önemli bir yeri vardır. Türklerin İslamiyet'i kabul etmesinden çok daha önceki dönemlerden başlayarak günümüze kadar, çeşitli şekillerde dua konusunun işlendiği, manzum, mensur veya manzum-mensur pek çok eser vücuda getirildiğ $i$ görülmektedir. Duânâmeler de bu tür eserler arasindadir. Duânâmelerin, dua konusuyla ilgili münâcat, tevbename, ilticaname gibi diğer türlerden farkı, duanın bir başkası için edilmesidir. Klâsik Türk edebiyatında da bu konuda yazılmış pek çok eserle karşılaşılmaktadır. Mesnevî tarzında yazılmış müstakil duânâmelerin yanı sıra kaside, gazel, kıt'a gibi diğer nazım şekilleriyle yazılmış duânâmeler de mevcuttur. İlmînnin "Duânâme"si de mesnevî nazım şekliyle yazılmış, 107 beyitten müteşekkil, müstakil bir eserdir. Sultan IV. Murad için kaleme alınmıştır. Bu eser aynı zamanda bir cülûsiye olarak da kabul edilebilir. Aynı zamanda Bağdat ve Yemen'in fethi için yazılmış bir fetih duası özelliğini taşımaktadır.

A N A H T A R K E L İ M E L E R

Duânâme, Klâsik Türk edebiyatı, Kadizâde Mehmed İlmî, Sultan IV. Murad
A B S T R A C T

The subject of "prayer" has a crucial place in Turkish culture and literature. It is seen that the subjects of "prayer" were discussed in various methods before the acceptance of Islam by Turks and verse, prose or verseprose works related to the "prayer" were formed in this period. The difference of duânâme from other forms like "münâcât, tevbenâme, ilticânâme" is that the duânâme is a pray for another person. There are many works which related to this subject in Classical Turkish Literature. Besides autonomous "duânâme"s formed in masnawi style, there are various "duânâme"s written in other verse forms like qasida (panegyric), ghazal and kut'a. İlmî's "duanâme" is an autonomous work formed in masnawi prose style with 107 couplets. The work was written for Sultan Murad IV. This work, at the same time, can be accepted as a "cülusiyye". However, this work has a conquest prayer characteristic which had been written for conquest of Baghdad and Yemen

K E Y W O R D S

Duânâme, Classical Turkish Literature, Kadızâde Mehmed İlmî, Sultan IV. Murad

İnsan, hangi dine mensup olursa olsun, manevî dünyasında inandığı yüce varlığa değişik şekillerde ve konularda halini arz etme, ondan istekte bulunma ve ona şükr edip onu yüceltme, kısacası dua etme ihtiyacı duyar. Bu sebeple dua, insanın, inandığı bu yüce varlıkla kendisi arasında kurduğu, ona doğrudan doğruya ulaşabileceği sağlam bir ma-

“ Prof. Dr., Marmara Üniversitesi Fen-Edebiyat Fakültesi Türk Dili ve Edebiyatı

Bölümü, İstanbul. (sebahat@marmara.edu.tr) 
nevî köprüdür. İnsan hayatında bu derece rolü olan duanın toplumların dinî kültürlerinde de önemli bir yeri vardır. İslam inancını benimsemiş toplumların dua konusundaki en önemli kaynağ ise Kur'an-1 Kerim ve hadislerdir. Nitekim Kur'an'da da duanın önemini vurgulayan âyetler bir hayli fazladır. ${ }^{1}$ Dolayısıyla kültürel ve edebî mahiyetteki dualar da bunlarla ilgilidir. Ayrı bir inceleme konusu olan bu duaların bazıları tamamen dinî karakter gösterirken, bazılarının ise aynı zamanda farklı konular ihtiva ettikleri de görülmektedir.

Pek çok yönden zengin olan ve çeşitlilik arz eden Türk kültür ve edebiyatı, dua konusunda da aynı özelliği taşımaktadır. Asırlar boyunca muhtelif konularda manzum, mensur veya manzum-mensur karışık sayısız dua örnekleri teşekkül etmiştir. Bunlar arasında anonim örnekler olduğu gibi ferdî ve edebî mahsuller de mevcuttur. Ferdî ve edebî örnekler dışındaki duaları Prof. Dr. Âmil Çelebioğlu'nun tasnifiyle şu şekilde sıralamak mümkündür. Bir meslekle, tarikatla, gelenekle, sıhhatle, dinî, içtimaî bir vâkıayla vs. ile ilgili olarak çeşitli gülbanklar, yağmur duası, yemek duası, mevlit duası, aşure duası, nazar duası, hacı duası, mektep duası, kitap duası, bir işe başlama duası, sefer duası, çevirgel duası, battalname duası, Hizır duası, hatim duası, kayıt duası, yeni ay duası, ezan duası, hatime duası, esnaf duası, kadeh duası, yatak duası vs. dualar (Çelebioğlu 1983: 154). Bunlardan bazılarının edebiyatımıza yansımasıyla ilgili müstakil çalışmalar da yapılmıştır. ${ }^{2}$

Edebiyatımızda konuyla ilgili destanları, koşmaları, ninnileri, manileri vs. ile Halk şiiri, ilahîleriyle de Tekke şiiri bu yönden oldukça zengindir. Klâsik edebiyatımızda ise mensur örnekler haricinde manzum olarak genellikle kaside ve mesnevî nazım şekilleriyle münacat, tazarruat, niyazname, istimdadiyye, tevbename, istiğfarname, ilticaname gibi türlerde büyük, küçük pek çok eser vücuda getirilmiştir.

Türk edebiyatında dua konusuyla ilgili ilk örnekler Türklerin İslâmiyeti kabul etmeden önceki dönemine rastlar. Uygurların Mani

\footnotetext{
${ }^{1}$ Mü'min 40/60 (Meâli: Bana dua edin, duanızı kabul edeyim.), Furkan 25/77 (Meâli: Duanız olmasa Rabbim sizi neylesin?), Bakara 2/186, Nîsâ 4/32,117,134, A'râf 7/29, 55, 180, Yûsuf 12/86, vs.

${ }^{2}$ bkz. (Çelebioğlu 1987: 95-102), (Ceylan 2005: 182-193).
} 
dinini benimsedikleri döneme ait olan dua ve ilahiler bunların ilk örnekleri sayılabilir. Bilinen ilk Türk şairi olarak kabul edilen Aprın Çor Tigin'in Mani için yazmış olduğu medhiye (Arat 1986: 14-17) de bunlar arasına dahil edilebilir. Yine bu döneme ait olan Tan Tanrı ilahisi (Arat 1986: 5-9) ise münâcat ve dua türünün bilinen ilk örneği olarak kabul edilebilir. Budist Uygurlar arasında edilen tövbe ve hâtime duaları da bu konuda zikre değerdir (Arat 1986: 177-183, 213-242). Türklerin İslâmiyet'i kabulünden sonra meydana getirdiği eserler ise dua konusunda daha zengin malzemeye sahiptir. Bunların en başında Dede Korkut Hikâyeleri gelir. Bu hikâyelerin sonlarında genellikle Dede Korkut'un "Yom vereyin Hânum" (Dua edeyim Hânım) şeklinde başlayan duaları yer almaktadır. Genellikle birbirine yakın ifadelerle hikâyenin kahramanı için edilen bu dualar, duânâme türünün belki de ilk örnekleri olarak kabul edilebilecek niteliktedirler. ${ }^{3}$

Daha sonra Karahanlılar döneminde Türk edebiyatının ilk şaheseri olan Kutadgu Bilig'de klâsik mânada tevhit ve münâcat türlerinin en eski örnekleriyle karşılaşılmaktadır. Ayrıca eserin içinde Odgurmuş'un hükümdar Küntoğdu için yaptığı dualar da mevcuttur. Ahmed Yesevî́nin Dîvân-ı Hikmet'indeki manzumeler de dua konusunda oldukça zengindir. Orta Asya'dan Anadolu'ya gelindiğinde bu konuda ilk

${ }^{3}$ Örnek olarak Dede Korkut'un Dirse Han oğlu Boğaç Han için söylediği duayı burada vermek yerinde olacaktır.

Yom vireyin Hânum!

Yarlu kara tağlarun yıkılmasun!

Gölgelice kaba ağacun kesilmesün!

Kanın akan görklü suyun kurumasun!

Kanadlarun uçları kırılmasun!

Çaparken ağ boz atun büdirmesün!

Çalışanda kara polat uz kılıcun gedilmesün!

Dürtüşürken ala gönderün ufanmasun!

Ağ bürçekli anan yiri behişt olsun!

A ğ sakallu baban yiri uçmak olsun!

Hak yanduran çırâğun yanadursun!

Kâdir seni nâmerde muhtâc etmesün!

Ol ögdügüm yüce Tanrı dost olub meded irsün!

Hânum sana, cânum sana! (Tezcan ve Boeschoten 2001: 214). 
akla gelen isimler Mevlânâ ve Yunus Emre'dir. Bundan sonra Osmanlı döneminde Divan, Tekke ve Halk edebiyatı olmak üzere birbirine paralel üç mecrada hızla gelişen Türk edebiyatı, dua konusunda sayılamayacak kadar çok malzeme ortaya koymuştur.

Klâsik Türk şiirinde, Fuzulî Divanı'nda olduğu gibi, genellikle divanların başında münacat türü şiirin bulunması bir tertip özelliğidir. Hatta bazen gazeller bölümünün başlangıcında da bu temanın işlendiği görülebilir. Özellikle "yâ Rab" redifli gazeller bunlar arasında zikredilebilir. Ayrıca mesnevî nazım şekliyle kaleme alınmış müstakil eserlerin başında veya sonunda münâcat muhtevalı kısımlar yer alması da tertip gereğidir. Bu sebeple pek çok divanda ve mesnevîde bu özellikle karş1laşmak mümkündür. Kasidelerin son bölümleri ise dua bölümü olarak adlandırılır. Edebiyatımızda nesib veya teşbib bölümü, girizgahı ya da tagazzülü olmayan kasidelerle karşılaşmak mümkündür, ancak dua bölümü olmayan kaside yok gibidir. Nef'î́nin de, Ey Nef'î! Söylenecek söz kalmadı, artık lafı bırak (da dua et, sen de bilirsin ki), kaside yazmanın kanunu, (onu) tamamladıktan sonra dua etmektir, dediği aşağıdaki beytinde belirttiği gibi bir kasidenin dua ile sona erdirilmesi şiirde bir kanun gibidir.

Söz âhir oldı ko lâfı ey Nef'î

Tamâm olunca du'âdur kasîdede kânûn (Akkuş 1993: K. 58/51, 246)

Bunun yanısıra Nâbî́nin "dua" redifli aşağıdaki gazelinde olduğu gibi, baştan sona dua konusunu işleyen gazeller de mevcuttur.

Nice mümkin ki tahallüf ide te'sîr-i du'â

Halka-i sıdkdan oldukça cehân tîr-i du'â

Olur elbetde nişânek-zen-i meydân-1 kabûl

Pençe-i ma'siyet olmazsa 'inân-gîr-i du'â

Olmasa olmaz idi tâk-1 kabûle peyvend

Lafz-1 âmîndeki nûn halka-i zencîr-i du'â

Vechi var eyleseler ehl-i du'â şerminden

Rûyına destlerin perde-i taksîr-i du'â

İtse mânend-i güvâre n'ola pür-şehd-i kabûl

Günbed-i 'âlemi feryâd-1 zenâbir-i du'â 
Âşiyân eyler ise evc-i icâbetde n'ola

Lâne-i lebden uçan murg-1 hevâ-gîr-i du'â

Nâbiyâ sahn-1 zaferde ider inşâ'a'llah

Küleh-i düşmeni endâhte şemşîr-i du'â (Bilkan 1997: I, G. 9, 459)

Bunlardan başka herhangi bir şiir içinde dua mahiyetinde misra veya beyitlerle de karşılaşılmaktadır. Çeşitli duaların konu edildiği, dua isimlerinin zikredildiği, duanın teşbih unsuru olarak kullanıldığı, duanın gerekliliğinin vurgulandığı, duanın ediliş şeklinin (el açmak, yüzü Hakk'a çevirmek, eli yüze sürmek, baş açıp dua etmek, elleri aşağ1 doğru çevirmek, vs.) belirtildiği, ölünün arkasından dua etmenin işlendiği, ağzı dualı olmak, dua kapısı, dua eli gibi deyimlerin yer aldığı beyitler de azımsanmayacak kadar çoktur.

Ayrıca yukarıda anılan cevşen duası, devlet duası, Hızır duası, İsmi a'zam duası, kabir duası, kadeh duası, kılıç duası, yağmur duası, nazar duası, sabır duası, vuslat duası vs. dualar da beyitlerde çeşitli şekillerde işlenmiştir. Bu tür beyitlerde duaların tesirleri ve hangi durumlarda okunmaları gerektiği hususunda ipucu yakalamak da mümkündür. Başlı başına bir inceleme konusu olan bu dualara sadece birkaç örnek vermekle yetineceğiz.

Gazâlarda $d u$ 'â-yı cevşenine çâre kılmazdı

Özün her nice kılsa tecrübe tîr-i imtihân hançer (Fuzûlî) (Akyüz vd. 1958: K. IV/23, 27)

Dâyim el üstinde tut devlet du'âsın Âhiyâ

Şükr ü minnet Râzık'a el yüze sürmekdür meges (Âhî) (Sungur 1994: K. 1/12, 73)

Dâyire çizmiş $d u^{\prime} \hat{a}-y ı$ Hızr ile tâ hatt-1 yâr

Emriyâ mihr ü meh-i tâbânı teshîr eylemiş (Emrî) (Saraç 2002: G. 224/5, 139)

Hûb teshîr itmek içün bir du'âsı müstecâb

İsm-i A'zam okumış dînâr $\mathrm{u}$ dirhem üstine (Behiştî) (Aydemir 2000: G. 467/4, 484)

Hemîşe zikrüm olupdur benüm şarâb-1 zâhid

'Aceb mi virdün olursa senün $d u^{\prime} \hat{a}-y \imath$ kadeh (Aynî) (Mermer 1997: G. 98/2, 374) 
T11ısm-1 mâr idi kâkül cemâli gencine

Du'â-yı seyf ile bozıldı ol tılısm ey yâr (Emrî) (Saraç 2002: G. $177 / 2,119)$

Ölür dil zülf ü çeşm ü kaddün içün

İrişmezse ana vaslun du'âsı (Aynî) (Mermer 1997: G. 447/5, 637)

Bunun yanısıra dua kelimesi de beyitlerde teşbih unsuru olarak çeşitli hayallerle yer almaktadır. Ay, dilber, hediye, inci, ip, kadeh, kılıç, kilit, ok, rüzgar, semt, yay, yol, yüzük vs. duanın benzetildiği unsurlardan bazılarıdır. Dua, Allah'ın nurunu ihtiva etmesi ve ard arda edilmesi bakımından etrafında kat kat haleler bulunan aya; istikametinin göğe doğru olması açısından salıncağa binip sallanırken göğe doğru yükselen bir dilbere; başkası için edildiğinde hediyeye; değerli ve mânen nurlu olması bakımından inciye; peş peşe edilmeleri sebebiyle inci dizilen ipe; dilden hiç düşürülmemesi özelliğiyle elden düşmeyen kadehe, rakibi yardan ayırmak için edilmesiyle kılıca; Allah'a ulaşmasıyla oka; bir işin istenilen şekilde sonuçlandırılabilmesindeki etkisi açısından rüzgara; manevî anlamda herkesin gitmesi gereken bir semte; hedefi yakalamaya vesile olması bakımından yaya; bir ömür boyunca edilmesi itibarıyla yola; edebî anlamda eserin sonunu ifade ettiği için mühüre vs. benzetilmiştir. Bunlar arasında en sık karşılaşılanı ise dua-ok benzetmesidir. Dua, kulun doğrudan doğruya Allah'a hitabıdır ve başka hiçbir yere sapmadan ona ulaşır. Duanın Allah katında kabul görmesi için temizlenmiş bir kalple ve samimiyetle edilmesi gerekir. Ok da sağlam ve iyi gerilmiş bir yaydan fırlatıldığı zaman hedefi bulur. Aksi takdirde nişana ulaşması mümkün olmaz. Bu iki unsur arasındaki büyük benzerlik şairlerin şiirlerinde dua-ok teşbihine sıkça yer vermelerine sebep olmuştur. Aşağıdaki beytinde Necâtî Beğ, sevgiliyi âşı̆̆ın âhından sakınması konusunda ikaz ederken, mazlumun duasının Allah katında kabul edileceğine de işaretle duayı oka benzetmiştir.

Ey mâh-çihre 'âşıkun âhından it hazer

Bilmez misin ki göklere tîr-i du’â çıkar (Necâtî) (Tarlan 1963: G. $78 / 6,193)$

Azmizâde Haletî de aşağıdaki beytinde duayı yay ile ilgi kurarak oka benzetmiştir. Burada şair, Hz. Peygamber'in duasını, kâbe kavseyn'e ulaşan bir ok olarak tasavvur etmiştir. Bunu da Kur'ân'da, Necm suresi- 
nin, "fe-kâne kâbe kavseyni ev ednâ", meâlen; böylece peygambere olan mesafesi iki yay aralı̆̆ı kadar, yahut daha da az kaldı (Yılmaz 1992: 52), şeklinde buyurulan 9. âyetinden iktibasla ifade etmiştir.

Hakk'a şükr eyledi Resûl-i Hudâ

Kâbe kavseyne irdi tîr-i du'â (Azmizâde Hâletî) (Kaya 2003: Mes. $4 / 35,38)$

Ayrica,

Ya köprü kur geçir beni dereden

Ya nefes et su çekilsin aradan (Ömer Kayaoğlu)

misralarında görüldüğü gibi "nefes" kelimesi de bazen dua anlamina gelmektedir (Yavuz 1999: 41).

Yukarıdan beri kısaca temas edilmeye çalışılan hususlar, başlı başına ayrı bir çalışma konusu olup ${ }^{4}$ bu kadar bilgi vermenin yeterli olacağı kanaatiyle bu çalışmanın asıl konusu olan duânâmeye geçmek yerinde olacaktır.

Duânâme, Arapça "dua" ve Farsça "nâme" kelimelerinin birleşmesinden meydana gelen birleşik bir isimdir. Dua kelimesi, "çağırmak, seslenmek, istemek; yardım talep etmek" mânasındaki da'vet ve $d a^{\prime} v \hat{a}$ kelimeleri gibi masdar olup, isim olarak da "küçükten büyüğe, aşağıdan yukarıya vâki olan talep ve niyaz" anlamındadır. Dinî terim olarak ise "kulun bütün benliğiyle yüce yaratana yönelerek ondan istek ve dilekte bulunması ve bu amaçla icra edilen ibadet şekli olarak tarif edilir (Cilacı 1994: 529). Nâme kelimesi, isim olarak "mektup, sevgiliye ve aşka dair yazılmış mektup; kitap, mecmua", sıfat olarak "yazılı, yazılmış, küçük kitap" anlamında birleşik kelimeler yapar. Duânâme ise edebî anlamda bir kimsenin Allah'ın karşısında aczini itiraf ederek sevgi ve tâzim duyguları içinde O'ndan lütuf ve yardım isteğini dile getirdiği eserlere denir. Bu eserler manzum, mensur veya manzum-mensur olabilir. Henüz bir tür olarak ortaya konulmamış olan manzum duânâmeler, görme imkanı bulabildiğimiz mevcut örneklere göre iki beyitten başlayıp yüz-

\footnotetext{
${ }^{4} \mathrm{Bu}$ konuyla ilgili olarak kısmî bir çalışma yapılmıştır: Mustafa Can, 15-18. yy.larda Bazı Divanlarda Dua ve Beddua Beyitleri, Afyon Kocatepe Üniversitesi, 2001, XII+143 s.
} 
lerce beyte ulaşabilmektedir. Divanlarda ve şiir mecmualarında, Klasik Türk şiirinde kullanılan nazım şekillerinin hemen hepsiyle yazılmış duânâme örneklerine rastlamak mümkündür. Ancak bu konuda daha çok kaside ve kıta nazım şeklinin tercih edildiği ve bunların da duânâme veya duaiyye başlığıyla verildiği görülmektedir. 17. yy. şairlerinden Vahyî'nin "Kasîde-beççe-yi Du'ânâme" başlıklı 13 beyitlik kasidesi (Dî̀vân-ı Vahŷ̉: 31a-31b), Nâbî'nin "Kasîde-i Du'âiyye bâ-mukâbele-i 'Atiyyei Âsafiyye" başlıklı 21 beyitlik kıt'a-i kebîresi (Bilkan 1997: II, 1127-1129) bunlara örnek verilebilir. Ayrıca Hayâlî Beğ'in Divanı'nda hem "du'ânâme" (Tarlan 1945: 89), hem de "ez-Eş'âr-1 Gül-i Sadberg" (Tarlan 1945: 367) başlığıyla mükerrer bir şekilde yer alan "aşk eyle" redifli 11 beyitlik gazeli ve Gaziantepli Tâhir'in (doğ.1133/öl.?) "Târih-i izin ve du'â-yı Tâhir Efendi" başlıklı kıt'ası (Sabri 1934: 15) da bu kabilden manzumelerdir. Bazıları ise duânâme olduğunu belirten herhangi bir başlık altında yer almasa da, Nâbî̀nin yukarıda verilen "dua" redifli gazeli gibi konu itibarıyla duânâme özelliğini taşımaktadır. Ayrıca mesnevî nazım şekliyle yazılmış müstakil duânâmeler de mevcuttur. Bu çalışmanın konusu olan "Du'ânâme-i İlmî" bu tür örneklerden biridir.

Konu bakımından duânâmelerin, daha çok bir başkası için edilen duaların işlendiği manzumeler olduğu söylenebilir. Özellikle padişahlar için ömürlerinin ve saltanatının uzun, muzafferiyetlerinin daimî olması konusunda duânâmeler yazılmıştır. Diğer devlet büyükleri ile tasavvuf ehli şairlerin, mensubu oldukları tarikatın şeyhi veya değer verdikleri bir pîri için yazdıkları duânâmelere rastlamak da mümkündür. Ayrıca edebî anlamda âşı̆̆ın dilinden sevgilinin ömrünün uzun olması konusunda yazılmış duânâmeler de mevcuttur. Böylece duânâmeler, münâcat, tazarruat, niyazname, istimdadiyye, tevbename, istiğfarname, ilticaname gibi türlerden farklı olarak değerlendirilebilir. Zira bu tür manzumelerde günahlarının affedilmesi ve lütfuna, yardımına nail olma hususunda şairin kendisi için Allah'a yalvarması söz konusudur. Duânâmelerde esas olan ise bir başkası için dua etmektir. Ancak duânâmeler de önce şairin kendi aczini, günahkârlığını dile getirip affedilmesini dilemesiyle başlar; daha sonra şiiri kim için yazmışsa ona dua ederek devam eder. Çalışmamızın konusunu teşkil eden İlmî̀nin Duânâme'si de Sultan IV. Murad için kaleme alınmış bir eserdir. 


\section{Müellifi}

Eserin müellifi Kadızâde Mehmed Efendi, dönemin meşhur âlimlerindendir. 990/1582'de Balıkesir'de doğmuştur. Babası Toganizâde Mustafa Efendi adında bir kadıdır. Mehmed Efendi kadı oğlu olduğu için Kadızâde lakabıyla anılmış ve meşhur olmuştur. Gençliğinde Balıkesir'de Birgili Mehmed Efendi'nin talebelerinden dersler alarak başladığ1 tahsilini daha sonra İstanbul'a gelerek burada tamamlamıştır. Bir süre sonra tasavvufa ilgi duyarak İstanbul'da Halvetî şeyhlerinden Tercüman Tekkesi şeyhi Ömer Efendi'ye intisap etmiş, ancak tasavvufun onun mizacina ve fikirlerine uymaması sebebiyle bu yoldan feyz alamayıp eski mesleğine, vaizlik ve müderrisliğe geri dönmüştür. İyi bir hatip olması sebebiyle kısa zamanda meşhur olmuştur. Bir ara Aksaray'da Murad Paşa Camii'nde muhtasar ve hüsn-i tâbir gibi dersler vermiştir. Ardından Birgilizâde Fazlullah Efendi yerine Sultan Selim Camii vaizi olmuştur. Daha sonra meslekteki rütbesi artarak 1032/1623 yılında Sultan Bayezid Camii'ne nakl olunmuştur. 1038/1628-29 y1lında Fatih Camii'nde görev yapmıştır. 1041 yılının Cemâziye'l-âhirinde/Aralık 1631'de Süleymaniye Camii'ne ve aynı yılın sonunda 1632'de de Ayasofya Camii'ne geçmiştir. Buradaki vaazları ve dersleriyle şöhreti iyice artmıştır. Bu görevine devam ederken orduyla beraber IV. Murad'in ilk Bağdat (Revan) Seferine katılmış; ancak yolda rahatsızlanıp Konya'dan geriye dönmek zorunda kalmış, 1045 Zilkâde/Nisan 1636 tarihinde vefat etmiştir. Naaşı, Topkapı dışındaki şeyhler kabristanına defnedilmiştir. ${ }^{5}$

Kadızâde Mehmed Efendi, aynı zamanda tarihte "Kadızâdeliler hareketi" olarak bilinen tartışmaları başlatan kişidir. ${ }^{6} \mathrm{O}$, âlimliğin yanısıra

${ }^{5}$ Kadıâde Mehmed Efendi'nin hayatı ile ilgili bu kısa bilgiler şu kaynaklardan özetlenmiştir: Bursalı Mehmed Tahir Efendi, Osmanlı Müellifler, 1, (haz.A. Fikri Yavuz-İsmail Özen), İstanbul: Meral Yay., 373; Kâtib Çelebi, Mizânü'l-Hak fi İhtiyâri'l-Ahak, (haz. O. Şaik Gökyay), İstanbul, 1972, 108; Kâtib Çelebi, Fezleke, İstanbul 1287, II, 182; Nâimâ Tarihi, III, 275; Şeyhî Mehmed Efendi, Şakâik-i Numâniye ve Zeyilleri III. Vekâyiu'l-Fudalâ I. (haz. Abdülkadir Özcan), İstanbul, 1989, 59-60; Semiramis Çavuşoğlu, "Kadıâdeliler", DİA, 24, İstanbul: TDV Yay., 2001, 100.

${ }^{6}$ Kadızâde Mehmet Efendi'nin Abdülmecid Sivâsî ile aralarında cereyan eden bu tartışmaların konuları şu üç kategoride toplanmıştır: 1. Tasavvufî düşünce ve semâ, devran, zikir ve musikî gibi uygulamalarla ilgili meseleler. 2. Müspet ilimleri 
şairlik kabiliyetine de sahiptir. Şiirlerine mecmualarda rastlanmakta olup bazen "Kadızâde" lâkabıyla bazen de "İlmî" mahlasını kullanarak şiir yazmıştır. Ulema sınıfına mensup olması sebebiyle bu mahlası kullandığı anlaşılmaktadır. Şiirlerinden "bilmiş ol" redifli 55 beyitlik kasidesi ${ }^{7}$, Sultan Murad'a nasihatname olarak kaleme aldığ dir. Dönemin meseleleri ve tedbirlerini ihtiva eden bu şiiri Kadızâde'nin, IV. Murad'ın yanındaki itibarına ve nüfuzuna güvenerek yazdığı anlaşılmaktadır. ${ }^{8}$ Sultan Murad'ın, Kadızâde Mehmed Efendi'nin düşüncelerine ve fikirlerine itibar ettiği, daima onu yakınında bulundurduğu ve bazı konularda onunla istişarede bulunduğu bilinmektedir. Bu çalışmanın konusu olan manzumesi ise onun, "İlmî" mahlasını kullanarak kaleme aldığı ve yine aynı padişah için yazdığı Duânâme'sidir.

\section{Eseri}

İlmî'nin bu eserinin farklı mecmualarda iki nüshası tespit edilebilmiştir.' Ancak manzumenin mukaddimesinde şairin, bu duânâmenin saray mescidinde ve diğer camilerde okunması hususundaki dileği yer almaktadır. Onun o dönemde Sultan Bayezid Camii'nde vaiz ve nâsıh olduğu dikkate alınırsa ve eserin Bayezid Kütüphanesi'nden başka Topkapı Sarayı Kütüphanesi'nde de bir nüshasının bulunmasından hareketle, duânâmenin diğer camilerde de okunmuş olması ve dolayısıyla

okumanın caiz olup olmadığı; Hızır'ın hayatta bulunup bulunmadığı; ezan, mevlid ve Kur'ân'ın makamla okunmasının caiz olup olmadığı; Firavun'un imanla ölüp ölmediği; Muhyiddin İbnü'l-Arabî'nin kafir sayılıp sayılmayacağı; Yezid'e lânet edilip edilmeyeceği; kabir ziyaretinin caiz olup olmadığı; mübarek gecelerde cemaatle nafile namaz kılınıp kılınamayacağı gibi dinî inanışlar ve ibadetlerle ilgili meseleler. 3. Tütün ve kahve gibi keyif verici maddelerin kullanılmasının haram olup olmadığ1; rüşvet almanın mahiyeti ve hükmü; namazlardan sonra musafahanın, inhinanın (el etek öpme, selam verirken eğilme) caiz olup olmadığ1 gibi sosyal ve siyasî hayatla ilgili meseleler (Çavuşoğlu 2001: 100). Bu tartışmaların yaygınlaşması sonucunda tarikat mensuplarına karşı bir düşmanlık ortaya çıkmış ve Mevlevî tekkelerinde âyin yapılamaz hâle gelmiştir ( Kâtib Çelebi 1287: II, 183).

${ }^{7}$ Konya İl Halk Kütüphanesi Feridun Nafiz Uzluk Bölümü, nr. 6994, yk. 5b-7b.

${ }^{8}$ Kadızâde'nin bu şiiri hakkında daha geniş bilgi için bkz. (Ürekli 1997: 277-300).

${ }^{9}$ Bunlardan biri Bayezid Devlet Kütüphanesi Veliyüddin Efendi Bölümü 1801 numarada kayıtlı mecmua içinde, diğeri de Topkapı Sarayı Kütüphanesi Emanet Hazinesi Kitaplığı 739 numarada kayıtlı mecmuada bulunmaktadır. 
başka nüshalarının da bulunması kuvvetle muhtemeldir. Ancak yapılan araştırmalar neticesinde şimdilik sadece ikisi tespit edilebilmiştir.

Mevcut nüshalarda eserin telifine veya istinsahına dair herhangi bir kayda rastlanmamıştır. Ancak Kadızâde Mehmed Efendî'nin Sultan Bayezid Camii'nde vaiz ve nâsıh olarak görev yapmağa başladığı tarih olan 1032/1623 yılı aynı zamanda IV. Murad'ın da tahta çıktığı yıldır. Dolayısıyla eserin, bu tarihte Sultan IV. Murad'ın tahta çıkışı sebebiyle yazılmış bir cülûsiyye olması kuvvetle muhtemeldir. Nitekim manzumenin başında yer alan mukaddime kısminda da doğrudan doğruya cülûsiyye olduğu ifade edilmemekle beraber eserin Sultan Murad'a hediye edildiği belirtilmiştir. Klâsik edebiyatımızda cülûsiyyelerin kaside nazım şekliyle yazılması bir gelenektir. Ancak Kadıâde Mehmed İlmî Efendi, bir din adamı olması sebebiyle, padişaha sunduğu bu cülûsiyyeyi diğer şairlerin olduğu gibi övgü dolu bir kaside olarak değil, ideal bir padişah olması için Allah'a dua ettiği, mesnevî nazım şeklinde bir duânâme olarak yazmayı tercih etmiş olmalıdır. Bu manzumede aynı zamanda Sultan Murad'ın Bağdat ve Yemen'i feth etmesi için de dua edilmektedir. Bu haliyle eser bir fetih duası özelliğini de taşımaktadır.

Mevcut olan her iki nüshanın başında da, eser başlamadan önce mukaddime mahiyetinde manzum-mensur karışık bir giriş kısmı yer almakta ve burada eserin kimin için yazıldığı, türü, kim tarafından yazıldı̆̆ı, yazılış sebebi belirtilmektedir. Buna göre eser, Sultan Murad Han ibn Sultan Ahmed Han ibn Sultan Mehmed Han için, duânâme türünde yazılmış bir mesnevîdir. O dönemde Sultan Bayezid Camii'nde vaiz ve nâsıh olarak görev yapan Şeyh Muhammed İlmî tarafından inşâ edilmiş ve İslâm padişahına hediye edilmiştir. Bu kısımda şairin, kendisinin bir duacı olduğunu ve bir duacının hediyesinin de dua olacağını belirttiği şu cinaslı beyti de yer almaktadır:

Du'âciyam du'âdur armağânum

Du'âcıdan du'âyı armağân um

Beytin ardından ise padişahın ordusunun Bağdat ve Yemen'i de feth etmesi dileğinde bulunulmaktadır. Bunun için de bu duânâmenin saray mescidinde ve diğer camilerde her Cuma gecesi yatsı namazından sonra okunup bütün ümmet-i Muhammed'in ona "âmin" demeleri gerektiği, bu vesileyle Allah yardım edip Bağdat ve Yemen'in fethedileceği 
ifade edilmiştir. Bilindiği gibi Bağdat'ın Osmanlı Devleti'ne hukuken bağlanması 29 Mayıs 1555'te Amasya muahedesi ile olmuştur. Bundan sonra Bağdat'ta Sultan IV. Murad'in babası olan Sultan I. Ahmed dönemine (1590-1617) kadar bazı aşiret ayaklanmalarından başka önemli bir hareket görülmemiştir. I. Ahmed dönemi ise Celâlî isyanları ve bunların bastırılmaları gayretleri içinde geçmiştir. I. Ahmed'den sonra merkezî otorite sarsılmış ve yeniden isyanlar başlamıştır. Bu karışıklıklar sonucunda Şah Abbas 1623 yılında Bağdat'ı kuşatıp teslim almıştır. Sünnî halka zulm edip katliamda bulunmuş; İmâm-1 Âzam ve Abdülkâdir Geylânî türbelerini tahrip ettirerek cami ve medreseleri ahır haline getirmiştir. Bundan sonra Osmanlı Devleti'nin ilk hedefi Bağdat'1 kurtarmak olmuştur. I. Ahmed'in yerine geçen oğlu IV. Murad çocuk denecek yaşta ve İstanbul'da karışıklıklar çıkmış olmasına rağmen Bağdat'i kurtarmak için harekete geçilmiş ve nihayet Bağdat, 1638 yılında tekrar Osmanlı idaresine girmiştir (Halaçoğlu 1991: 433-434). Şairin IV. Murad'ın tahta çıkışı sebebiyle yazdığı bu duânâmede Bağdat ve Yemen'in fethedilmesi dileklerini de dile getirmesi I. Ahmed döneminde Bağdat'ın kaybedilmesinden duyulan derin üzüntünün ve tekrar geri alınması konusunda duyduğu şiddetli arzunun tezahürü olarak değerlendirilebilir.

Mesnevî nazım şekliyle kaleme alınmış olan bu eser, 106 beyitten müteşekkildir. Eserin klasik mesnevî tertibine uygun olduğu söylenemez. Zira konu itibarıyla baştan sona dua mahiyetinde olduğu için tevhid, münâcât, na't, sebeb-i telif, asıl konu, hatime gibi klasik tertip bölümlerine ayırmak mümkün olmamaktadır. Ancak yine de bir tertip içinde değerlendirilecek olursa eserin ilk 20 beytinin münâcât, 21-96. beyitler arasının asıl konu yani Allah'ın padişaha ve ordusuna güç verip Yemen ve Bağdat'ın fethedilmesi için dua, 97-102. beyitlerin fahriye olduğu söylenebilir. Eser, hatime bölümü denilebilecek olan 103-106. beyitlerdeki dua ile sona ermektedir.

Bu manzume, aruzun hezec bahrinin "mefâ'îlün mefâ'îlün fe'vulün" kalıbıyla yazılmıştır. Eser vezin bakımından oldukça sağlamdır. Türkçe kelimelerde görülen imâleler, her dönemde bütün şairlerde görülen bir özelliktir. Bu tür imalelerin dahi az olması şairin kelimeleri özenle seçtiğini ve bu konuda ne kadar kabiliyetli olduğunu göstermektedir. Bura- 
dan hareketle İlmî'nin teknik olarak aruza hâkim bir şair olduğu söylenebilir.

Eser kafiye bakımından incelendiğinde şairin, genellikle Arapça ve Farsça kelimelerle kafiye yaptığı görülmektedir. Bu da konu itibarıyla normal karşılanabilecek bir durumdur. Kafiyede, Türkçe kelimeleri ise daha az kullanmıştır. Bunlar ol-bul (11), tapu-kapu (17), yol-sol $(51,56)$, yirine-yirine (55), ol-gel (90), göz-söz (91) şeklinde sıralanabilir. Bu kafiyeler arasında ol-gel kelimeleri arasındaki yarım kafiye haricinde diğerleri cinasın değişik türlerinde yapılmış tam, zengin ve tunç kafiye örnekleridir. Arapça ve Farsça kelimelerle yapılan kafiyelerden genellikle kafiye-i müreddefe ile karşılaşılmaktadır. Metinde yer alış sırasına göre bunlar: Pâk-nâk (1), Kur'ân-fermân (2), şâh-câh (5), 'arrâf-sarrâf (12), i'timâd-murâd (14), fakîr-hakîr (19), maksûd-merdûd (20), zemân-emân (22), zahîr-basîr (23), 'ibâd-Murâd (25), makhûr-mesrûr (26), âbâd-berbâd (28), dâd-murâd (29), inkıyâd-murâd (33), nûr-mesrûr (35), refîk-tarîk (38), murâd-bilâd (39), hâl-âl (40), zamîr-zahîr (41), memdûd-mes' ûd (45), tâbân-şitâbân (47), ma'mûr-meşkûr (49), ihsân-sultân (50), imâm-temâm (53), fesâd-ibâd (57), ahkâm-İslâm (60), ma'lûm-mazlûm (61), şâhzillu'llâh (62), Hân-Osmân (63), cihân-emân (64), mâl-pâmâl (65), tevfîktahkîk (66), kerîm-müstakîm (67), meskûn-efzûn (70), âsumân-bâdbân (72), kemâkân-'isyân (73), cünûd-cühûd (78), maksûd-Ma'bûd (83), karîn-hem-nişîn (87), hitâb-'itâb (88), makâm-tamâm (93), müşg-bîz-'itr-rîz (99), âsumân-cihân (100), yâd-âzâd (103), mes'ûd-cûd (106) kelimeleri arasındaki kafiyelerdir. Kârı-Bârî (27), vilâyet-himâyet (52), ikâmet-itâ‘at (54), şâyi'-zâyi' (58), kâ'im-ganâ'im (59), lâyık-'âyık (94), nihâyet-hidâyet (105) kelimeleri arasında ise kâfiye-i müessese bulunmaktadır. Eserde terk-derk (8), kahr-zehr (74) ise kafiye-i mukayyede bulunan kelimelerdir. Pâk-nâk (1), kalem-'alem (3), sûfî-sâfî (9), emr-'ömr (16), tapu-kapu (17), zemân-emân (22), hâl-âl (40), ziyâde-ziyâda (46), tâbân-şitâbân (47), yirine-yirine (55), yol-sol (51,56), tîze-nîze (77), Murâd-murâd (84), hitâb'itâb (88), göz-söz (91), cenân-cinân (98) kelimeleri ise aynı zamanda cinas sanatının çeşitli şekillerinin (tam, lâhık, nâkıs, vs.) örnekleridir. Eserdeki diğer kafiyeler ise sadece revî herfi ile yapılan normal kafiyelerdir. Şairin bunlardan başka Türkçe-Arapça veya Türkçe-Farsça kelimelerle kafiye yaptığı da görülmektedir. Kul-dil $(7,10)$, murâdım-adım (13), evbaş-kızılbaş (75), anı-câvidânı (86), makbûl-kul (104) kelimeleri 
bu şekilde kafiyelidir. Eserin kafiye konusunda dikkat çeken diğer bir özelliği ise kafiye kelimeleri arasında murad kelimesinin sık kullanılmış olmasıdır. Şairin bu tercihinin tesadüfî olmadığı, eserini Sultan Murad için yazmasından dolayı bu ismi özellikle vurguladığı söylenebilir.

İlmî́nin bu eserinde redif olarak genellikle Türkçe, çok az sayıda da Arapça ek ve kelimeler kullanılmıştır. Bunların çoğu, keremdürmültezemdür (18)'de olduğu gibi bir ekten meydana gelen rediflerdir. Daha az sayıda olmak üzere bir ek ve bir kelime (-un içün)(2), bir ek ve iki kelime (-i ola hemîşe)(42), sadece bir kelime (eyle)(95) ve iki kelimeden (ola ol)(62) müteşekkil redifler de mevcuttur.

Dil bakımından eserde Arapça ve Farsça kelimeler çokça kullanılmış olmakla beraber söyleyiş bakımından Türkçe hakimdir. Şair bu eserinde, Farsça ve Arapça terkiplere çok rağbet etmemiştir. Bu tür terkipler manzumenin geneline oranla oldukça az sayılacak miktardadır. Üslup olarak ise eserde, son derece akıcı ve samimi bir ifade tarzı görülmektedir. Bu da şairin Allah'a yakarışındaki samimiyetin tezahürü olarak değerlendirilebilir. Muhatap doğrudan doğruya Allah olduğu için eserde konuşma üslubu hakimdir. Dua kısmında beyitlerin her biri bir dua cümlesi mahiyetinde olup, dinleyenler tarafından her birinin akabinde âmin denilmesi gerektiği hissedilmektedir. Nitekim şairin de eserinde zaman zaman âmin diyenler için "âmin diyen emin olsun belâdan" şeklinde duada bulunduğu görülmektedir.

Muhteva bakımından eser baştan sona dua konuludur. Şair, eserinin başında önce Allah'ı tâzim ettikten sonra mukaddes olan bazı unsurları ve insanları överek, bu övgüleri hem Allah'ın rızasını kazanmak hem de kendi duasının kabulünü kolaylaştıracak birer vesile olarak görmektedir. Bunlar sırasıyla Kur'ân-1 Kerim, Levh-i mahfuz ve kalem, Arş, Kürsî, Hz. Peygamber ve ailesi, diğer peygamberler, sahabe, velîler, ve Allah katında makbul olan diğer insanlardır. Bu kısımda şair önce, Allah'ı her türlü kirden münezzeh olan pâk zatıyla ve nur olan sıfatıyla zikretmiştir. Ardından da O'nun vasfını taşıyan Kur'ân'ın hakikati anlatan bir ferman olduğunu belirtmiştir. Levh-i mahfuza yazılan ilmi övmüş, Arş'in ve Kürsî̀nin azametini anlatmıştır. Hz. Peygamber'in, diğer peygamberlere üstünlüğünü anlatmak için peygamberlik tahtının sultanı olduğunu vurguladıktan sonra diğer peygamberleri, Hz. Peygam- 
ber'in ailesini ve ashabını da zikredip Allah katında makbul olan kulları tarif etmiştir. Bunlar, Allah'a yakınlık makamına kavuşmuş, gönülleri korku ateşiyle yanan, Kur'ân'ın mahiyetini idrak edip ona uyarak bu dünyayla her türlü bağını koparan, gönlünü her türlü dünyevî arzu ve isteklerden arındırıp sufî olan, Allah'ı seven ve onun sevgisini kazanan, Kur'ân'ın hikmetlerini kavrayıp geleceği anlayan, onun potasında eriyen, ondan başka şeye değer vermeyen kullardır. Bu kısmın sonunda şair, yukarıda zikrettiği bu kimselerin Allah katındaki makbuliyetlerinin hürmetine kendi duasının kabul edilmesi dileğinde bulunur.

$\mathrm{Bu}$ dileğin arkasından kendi halini, inancının ne kadar sağlam olduğunu ve samimiyetini arz eder. Burada Allah'a inanıp güvenen herkesin muradının hasıl olacağı, ona sığınan kimsenin isteklerine kavuşacağı, onun emirlerine uyan kimsenin ömrünü huzur içinde geçireceği inancıyla kapısına geldiğini, buradan lutuf ve kerem umduğunu, bu sebeple de bu kapıdan bir adım bile ayrılmayacağını belirtir. Allah'ın Kerîm ismine istinaden lutfunun, ihsanının bolluğunu, kerem sahibi olduğunu, kapısının günahkâr, hor, hakir vs. ihtiyacı olan herkese açık bulunduğunu, ona gönülden dua edip halini arz eden kimseyi geri çevirmeyeceğini, Allah'a hitaben samimi bir üslupla onu över ve kendi duasını da kabul etmesi dileğinde bulunur. Aynı zamanda kendisinin günahkar ve âsî bir kul olduğunu da itiraf eder.

Bundan sonra şair, bu duânâmeyi yazış sebebi olan asıl konuya geçer. Burada şair, önce duasının, zamanın padişahı olan Sultan Murad ile ilgili olduğuna işaret eder. Ardından da padişah için Allah'tan hangi dileklerde bulunduğunu belirtir. Bu dilekler şöylece sıralanabilir:

1. Padişahın âdil olması ve adaletle hükmetmesi.

2. Ömrünün uzun olmasi.

3. Allah'ın, her işinde onu gözetip yardımcı olması.

4. Ona sığınak olması.

5. Onu âleme bağışlaması.

6. Onun bütün düşmanlarını şiddetli bir şekilde kahredip, yenilgiye uğratması.

7. Onun ahbaplarını sevindirmesi. 
8. Padişahın yaptığı her işin kutlu olması ve bütün dünyada takdir edilmesi.

9. Onun gönül evinin ilimle âbâd olması ve düşmanların ülkesini y1kması.

10. Adalet ve doğruluk yolunda yürüyüp izzet ve murad kâbesine ulaşması.

11. Düşüncelerinin daima halkın istekleri yönünde olması ve istek sahiplerini murada erdirmesi.

12. Onun temiz kalbinin şerî́atın zuhur ettiği yer olması ve bütün âlemi aydınlatan bir güneş gibi parlaması.

13. Allah'ın emirlerinden ve Peygamber'in sünnetinden ayrilmamasi.

14. İşlerinde hep Allah'ın emirlerini gözetmesi ve muradının hep adalet etmek olmasi.

15. Kılıcının günahkârlara tevbe ettirmesi ve yolunu kaybetmişlere yol göstermesi.

16. Zekasının bir güneş gibi parlak olması ve bütün dünyanın onun adaletiyle mutlu olmas1.

17. Hangi hayırlı işe başlarsa her şeye muktedir olan Allah'ın ona yardım etmesi.

18. Müheymîn (kainatın bütün işlerini gözetip yöneten) olan Allah'ın onu lüzumlu olan her isteğine kavuşturması.

19. Yardımını ona arkadaş, lutfunu ve yardımcılığını da yoldaş etmesi.

20. Muradının daima adalet ve ilim olması; ülkesinin her türlü beladan korunmuş olması.

21. Onun ilminin bütün haline hakim olup hiçbir hileye aldanmaması ve şeri'at üzre hükmetmesi.

22. Bütün cihanın ona boyun eğmesi ve her işinde adaletin ona rehber olmas1.

23. Adaletin her zaman onun emrinde olması ve düşmanlarının kırılması. 
24. Kemalinin artması ve doğrulukla, adaletle ömür sürmesi.

25. Yer yüzünde onun adaletinin hüküm sürmesi ve dostlarının mutlu olmasi.

26. Kudret ve yüceliğinin artması, bahtının açı olması ve ikbal güneşinin daima parlaması.

27. Onun yücelik güneşinin daima parlaması ve düşmanlarının en kisa zamanda kahrolması.

28. Onun zamanında İslamiyet'in yayılması ve Allah'in bu hususta ona yardımcı olması.

29. Cihanı adaletle bayındır hale getirmesi ve yaptığı işlerin Allah katında makbul olmasi.

30. Adalet ve ihsan Allah'ın emri olduğu için padişahın bu emirlere uymasi.

31. Şeriat kanunları ile yola çıkıp gittiği her yerde onunla hükmetmesi.

32. Onun adaletiyle ülkenin güvenlik içinde olması.

33. İslam hükümlerini yürütüp Müslümanlara imam olması.

34. Ülke sınırlarında bulunan komşularının daima onun emir ve yasaklarına itaat etmesi.

35. Zekatı alıp yerine ulaştırması ve böylece zorbaların kahrolması.

36. Yol kesicileri ve hirsızları ortadan kaldırması.

37. Kavgayı sona erdirip, fesadı ortadan kaldırması ve ibadet edenlerin şahitliğini kabul etmesi.

38. İslam hukukuna zarar gelmesini önlemesi.

39. Allah yolunda savaşıp, savaşta elde edilen ganimeti adaletle dağitmasi.

40. İslam hükmünü yürütmeye muktedir olup koruması.

41. Zalimin üzerinde mazlum hakkı birakmaması.

42. Onun cihan padişahı olması ve zıllu'llah (Allah'ın gölgesi) olan bir sultan olması.

43. Azametiyle adının bütün cihana yayılması ve düşmanlarının ondan aman dilemesi. 
44. Düşmanlarının, kendi ülkelerini ayaklar altına almasın diye ne isterse ona vermeleri.

45. Allah'ın faziletiyle ona yardım etmesi ve onun taklitten geçip hakikat ehli olması.

46. Allah'ın, bu cömert sultana hidayet eylemesi ve Sırat-1 müstakim'den kolaylıkla geçmesini sağlaması.

Buraya kadar sıralanmış olan dualar padişahın kendisi için edilen genel dualardır. Bundan sonra şair, bu duânâmede padişahtan beklentisini dile getirir. Şair bu kısımda, yaptığı duanın bir fetih duası olduğunu belirterek eserinin yazılış amacını açıkça bildirmektedir. Burada şair, yaşı küçük de olsa padişahın, babasının döneminde kaybedilen Bağdat ve Yemen'i geri alması ümidiyle bu manzumeyi yazdığını anlatır.

Du'â-yı feth irişsün âsumâna

Sabâ-yı nasr girsün bâd-bâna

Yemen yümn ile feth olup kemâ-kân

Mutî́ ola cemî̀-i ehl-i 'isyân

Harâb olsun ser-â-ser mülk-i evbâş

Kızıl kana boyansun hep Kızılbaş

Yehûdâ vü nasârîden denîler

Fürû-mâye 'akıl ser-geştenîler

'Alef olsun olar şemşîr-i tîze

İrişsün râfızî sadrına nîze

Dahı Bağdâdı feth itsün cünûdı

Kıralar cümle ol hamr-1 cühûdı

Duânâmenin sonunda şair, gelenek haline gelmiş olan dua tertibine uygun olarak önce padişahın atalarına rahmet dilemekte ve ardından da bu duayı dinleyip âmin diyenlerin muradlarına ermelerini niyaz etmektedir.

Şairlerin, eserlerinin sonunda kendi şiirini ve sanatkarlık gücünü övmesi tertip gereğidir. Burada da İlmî,

Sözün İlmî senün nûr-1 cenândur

Delîl-i mûsıl-ı hûr-ı cinândur 
Mu'anber kıl cihânı müşg-bîz ol

Mu'attar it meşâmı 'itr-rîz ol

Kelâmun kadrin irgür âsumâna

Ola kandîl-i nûrânî cihâna

dediği beyitlerinde sözlerinin gönülleri nurlandıracağını, cennet hurilerine kavuşmanın delili olacağını, cihana müşk serpip güzel kokular saçacağını, göklere erişip cihanı aydınlatacak kandil olacağını belirterek şiirini övmektedir. Ardından da bu duânâmeyi okuyanların, dinleyenlerin ve görenlerin el açıp padişaha hayır dualar etmelerini, padişahı dua ile anmalarını dilemektedir. Bunu yapanların gamdan kurtulmaları için de Allah'a dua etmektedir. Ayrıca bu duanın kabul edilmesi ve âmin diyenlerin emin olması için Allah'a niyaz etmektedir. Bunun akabinde şair aşağıdaki beyitlerle eserini noktalamaktadır.

Du'âmuz bula bununla nihâyet

Cihân halkına yâ Rab kıl hidâyet

Cemî'-i mü'minîni eyle mes' ûd

Ecib da'vâtenâ yâ Sâhibe'l-cûd

Eserin metni iki nüsha karşılaştırılarak aşağıda verilmiştir. ${ }^{10}$

10 Nüsha karşılaştırılmasında Bayezid Devlet Kütüphanesi'ndeki nüsha için B, Topkapı Sarayı Kütüphanesi'ndeki nüsha için $\mathrm{T}$ rumuzu kullanılmıştır. Düzeltmeler belirtilirken metin için $M$ kısaltması verilmiştir. 


\section{DU’Â-NÂME-İ ‘ÍLM ${ }^{\star}$}

$84^{\mathrm{a}} \mathrm{B}, 114^{\mathrm{b}} \mathrm{T}$

(1)Ekremü's-selātịn ve a'ẓamü'l-havāḳīn es-Sulțān Murād Huān ibn (2)es-Sulțān Aḥmed Ḩān ibn es-Sulțān Muhammed Huān hażretlerine (3)du'ā-nāmedür ki Sulțān Bayezīd-i Velì 'aleyhi'r-raḥmetü'l-'ulā (4)Cāmi'-i şerifinde ḥālā vā'iz ü nāṣı̣̣ olan Şeyh Muhammed 'İlmī (5)dā'îleri inşā idüp pādişāh-ı İslāma ihdā itmişlerdür. (6)Ḳabūl recāsı ile taḳabbelallāhu te'ālā bikabūlin ḥasenin.

Du’āclyam du'ādur armaḡānum

Du'ācıdan du'āyı armaġān um

(7)Bu du'ā-nāmeyi her cum'ā gicesi yatsu nemāzından soñra mescidde (8)bir kimse oḳuyup diñleyenler āmīn diseler sa'ādetlü pādişāhumuzuñ (9)'ömürleri uzun olup ve cemi'‘ murādları hāạsıl olup (10)ve Yemen ve Bağdād feth olup ve a'dā-yı (11)dīn ü devlet mag̉lūb (12) olmag̉a sebeb olur (13)inşā'allāhu (14)te 'ālā."

\footnotetext{
* Başlık: Merhūm ve mag̉fūr Kaḍıāde Meḥmed Efendi Raḥmetu'llāhi 'aleyh Du'ānāme bi-ismihi subḥānehu nes'elu iḥsānehu münācāt-1 Hudā ve 'arż-1 ḥācāt T, Bismi'llāhi'rraḥmāni'rrahịm B

* Bu mukaddime B nüshasında şu şekildedir: (1)Ekremü's-selāțin ve a'ẓamü'lhavākịin illā ve hüve's-(2)sulțān ibni's-sulțān es-sulțān Murād Hān (3)ḥażretlerine du'ā-nāmedür ki hạāā Sulțān Bayezīd-i Veli (4)'aleyhi'r-raḥmeti'l-ḳaviyy Cāmi'inde vā'iz ü nāṣıh olup (5)Şeyh Muhammed 'İlmī dā'î̀leri inşā idüp pādişāh-1 (6)İslāma ihdā itmişdür. Taḳabbelallāhu biḳabūli ḥasenin (7)recāsıyla.

Du'āclyam du'ādur armaġānum

Du'ācıdan du'āyı armag̉ān um

(8)Pes bu du'ā-nāme Saray mescidinde vesā'ir cevāmi'de (9)oḳınsa ve ümmet-i Muhammed āmīn diseler bi'avni'llāhi(10)te'ālā Yemen ve Bag̉dād fetḥ olup ve 'ālem emn ü emān (11)[ve] zemin ü zemān (ve) āsūde-hāal üzre olalar, (12)ve sa'ādetlü pādişāhumuz 'adliyle çoḳ mu'ammer (13)olalar bihüurmeti'l-fātihā
} 
84 B $115^{\mathrm{a}} \mathrm{T}$ Bismi'llāhi' rraḥmāni'rraḥīm

$$
\text { mefā'î̀ün mefā'î̀ïn fe' ūlün }
$$

1 İlāhī zaāt-1 pāküñ hürmeti-y-çün Ṣıfāt-1 tābnāküñ hüümeti-y-çün

2 Senüñ vașfuñ olan Kur'ānuñ içün Haḳı fark itmege fermānuñ içün

3 İlāhì levḥ-i maḥūẓ u ḳalem-çün Aña mektūb olan 'ilm ü 'alem-çün

4 Muhịtt-i cümle 'arş-1 a' ẓam içün Cinānuñ ferşi Kürsī Ekrem içün

5 Nübüvvet tahtınuñ ol şāhı içün Yanuñda ulu 'izz ü cāhı içün

6 İlāhì enbiyānuñ cümlesi-y-çün Dahı aṣhāb u āli zümresi-y-çün

7 Maḳām-ı ḳurba vāṣıl ḳullar içün O nār-1 havfa yanan diller içün

8 Kelāmuñla sivāyı terk iden-çün Kelāmuñ mánisini derk iden-çün

9 Ṣafālardan geçüp șūfī olan-çün Kelāmuñla senüñ șāfī olan-çün

10 Habīb ü hem muhibb olan ḳul içün Mürīd ü hem murād olan dil içün

1 tāb-nāküñ: tāb-nātüñ T

2 fermānuñ:Furḳānuñ T

${ }^{5}$ tahtınuñ: taḥtınuñ B

${ }^{8}$ derk: Bu kelime metinde terk şeklinde yazılmış olup anlam gereği bu şekilde düzeltildi. (derk: anlama, kavrama) 
11 Kelāmuñ pūtesinde șāf olan-çün Dürişüp 'ilmüñ iksirin bulan-çün

12 Kelāmuñda senüñ 'arrāf olan-çün Kelām-1 gàyrıda șarrāf olan-çün

13 Müyessirsin müyesser ḳıl murādum Kapuña geldüm ü gitmem bir adım

14 Şular kim saña itdi i'timādı Olur yanuñda hạạ̣ıl her murādı

$115^{\mathrm{b}} \mathrm{T} \quad 15$ Şular kim saña itdi ilticāyı Muḳarrer buldılar anlar recāyı

16 Şular kim saña tefvī̇̇ itdi emrin Hużūr ile geçürdi cümle ‘ömrin

17 Yüzüm tevcīh idüp yā Rab țapuña Kerem luṭ uma geldüm ben ḳapuña

85ª 18 Kerīmsin 'ādetüñ dā'im keremdür Ki ehl-i cürme bābuñ mültezemdür

19 Açuḳdur bāb-1 luṭfuñ her faḳire N’ola iḥsān iderseñ ben hạạire

20 Göñülden her kişi isterse maḳṣūd Virürsin eylemezsin anı merdūd

21 Murādum ol ḳabūl eyle du'āmı Kuluñam çünki ben 'àși vü 'āmìi

22 Du'ām oldur ki sulțān-ı zamānı Ḳ̂lup 'ādil viresin çoḳ emānı

\footnotetext{
${ }^{11}$ - B; iksīirin: ekşerin M (anlam ve vezin gereği düzeltilmiştir.)

${ }^{15}$ ilticāyı: ilticātı B. / / recāyı: recātı B

${ }^{19}$ ben:bu $\mathrm{T}$

${ }^{22} \mathrm{~T}$ nüshasında, bu beyitteki "emân" kelimesinin anlamı derkenarda "uzun ömürler ve çok muradlar" şeklinde açıklanmıştır.
} 
23 Olasın dā'imā anuñ ẓahīi

Her işinde mu'îni vü bașīi

24 Dahı fażluñla luṭf idüp İlāhì

Olasın sen Murād Hānuñ penāhı

25 İlāhì eyleyüp luṭfı 'ibādı

Bağışla 'āleme Sulțān Murādı

26 İdüp a'dāsını ḩışm-ile maḳhūr

Kamu aḥbāb-1 devlet ola mesrūr

27 Ola maḳbūl-i ‘ālem cümle kārı

Hümāyūn ide menşūrını Bārí

28 Ola beyt-i dili 'ilm-ile ābād

İde mülk-i 'adūyı tā ki berbād

29 Sülūk itsün țariḳ-1 'adl ü dāda

İrişsün Ka'be-i ‘izz ü murāda

116a T 30 Medār-1 emr-i cumhūr ola rāyı

Murād ehli bula andan recāyı

31 Dil-i pākin şeri' at maẓharı ḳıl

Cihānuñ āfitāb-1 enveri ḳıl

32 Senüñ emrüñi icrā ḳıl rıżāsın

Resūlüñ sünnetin ḳıl reh-nümāsın

33 Umūr-ı şer‘a ḳılsun inḳıyādı

'Adālet itmek olsun hep murādı

\footnotetext{
25 'ibādı : Bu kelimede datif eki olan -a, -e sesinin -1 sesiyle verildiği görülmektedir. Bu özelliğe bugün de Anadolu'nun bazı yörelerinde, özellikle Ege bölgesi ağzında rastlanmaktadır.

28 'ilm-ile:' ālemde B

${ }^{30}$ rāyı: rā'ì B / / recāyı:recā'ì B

${ }^{31}$ āfitāb-1 enveri:āfitāb-u enveri B

${ }^{33}$ itmek:etmek B; hep:her T
} 
34 Zebān-1 tịg 1 tevbe vire halḳa Hidāyet eyleye güm-rāh-1 haḳḳa

85 B 35 Zekāsı āfitābı ola pür-nūr Cihān 'adliyle ola şād u mesrūr

36 Ne kār-1 hayra kim ola mübāşir Aña teysīir ide Allāh-ı ḳādir

37 Murādātın virüp cümle Müheymīn Müheyyā eyleye dā'im mühimmin

38 İlāhì aña tevfīḳñ refịk it Meded-kārī-i fażluñ hem-țarīk it

39 Hemīşe 'ilm ü 'adl ola murādı Mașūn olsun belālardan bilādı

40 Muhịt ola 'ulūmı cümle hāle Ki tā aldanmaya her mekr ü āle

41 Muhịt olduḳda aḥvāle żamīi Şerī at emrinüñ ola zahīiri

42 Cihān fermān-beri ola hemişse 'Adālet rehberi ola hemişse

43 Hemişse 'adl ola aña müyesser 'Adūsı ola her demde mükesser

44 Kemāli arta dā'im ola enver Cihānda 'adl ile ola mu'ammer

$116^{\mathrm{b}} \mathrm{T} 45$ Zemīn üstinde 'adli ola memdūd Hemişse hem-dem ola 'adl-i mes' ūd

\footnotetext{
${ }^{34}$ zebān:zübān B

${ }^{35}$ şād u: - B

${ }^{37}$ murādātın:murādā B; Müheymīn:mühimmin T / / - B

45 'adli ola:ola 'adli B
} 
46 Ola hem 'izzet ü bahşs ziyāde

Dahı hưrşīd-i iḳbāli żiyāda

47 Şu'ā'-1 mihr-i rif'at ola tābān

'Adūsınuñ ola ḳahrı şitābān

48 Zamānında şeri' at ola cārī Huudā her işde ḳılsun aña yārī

49 Ol 'adl ile cihānı ide ma' mūr Hudā ide anuñ sa'yini meşkūr*

50 Hudānuñ emridür çün 'adl ü iḥsān Ol emre imtisāl ide bu sulțān

51 Gire ol şer ü ḳānūn ile yola Anuñla hü̈km ide șağ ile șola

86 B 52 Anuñ eyyām-1 'adlinde vilāyet Olup emn üzre hem ola hịimāyet

53 Ola ol ehl-i İslāmuñ imāmı Ki tenfīz ide aḥkāmı tamāmı

54 Hudūdı eyleye dā'im iḳāmet İdeler emr ü nehyine ițā'at

55 Zekātı alup ol vire yirine Tagallüb ehli ḳahrından yirine

\footnotetext{
${ }^{46}$ bahşı: bahtı B

${ }^{47}$ şu'ā' :şi'āa B / / şitābān:sitābān B

* Bu beyitten sonra T nüshasında 50 . beyitle alakalı olarak

Kāle'llāhu el-Melikü'1-Mennāni'd-Deyyān

İnne'llāhe ye'muru bi'l-'adli ve'l-ihssān,
} şeklindeki, âyet ihtiva eden Arapça beyit, B nüshasında ise "Nev'-i diger der du'ā-i pādişāh-1 a z̧am" başlığı yer almaktadır. Bu başlık ikinci bir duānāme olduğu hissini uyandırmaktadır. Ancak beyitlerin devamına bakıldığında, birinci duānāmenin burada bitmediği ve ikinci kısmın onun devamı olduğu anlaşılmaktadır. 
56 Ne ḳuțțā'-1 țarị̄̂ ḳoya yolda

Ne uğrılık ideni șaǵ u șolda

57 Nizā‘ 1 ḳaṭ u ref' ide fesādı

Kabūl ide şehādāt-1 'ibādı

58 Cihānda emr-i şer 'i ide şāyi

Huḳūḳ-1 müslimīn olmaya żāyi‘

117a T 59 Cihād idüp ġazāda ola ḳā'im İde 'adl ile takssimm-i ganā'im

60 Oluban ḳādir-i tenfīż-i aḥām İde ḥ̂fẓ-1 ḥudūd-1 dār-1 İslām

61 Hem inṣāf ile ide Haḳkı ma'lūm Komaya zāalim üzre haḳk-1 maẓūm

62 Murād oldur cihāñda şāh ola ol Ki es-sulțānu ẓıllu'1lāh ola ol

63 Cihānuñ cānıdur Sulțān Murād Hoān Güzīn-i dūdmān-1 āl-i ‘Ossmān

64 Mehābetle tuta nāmı cihānı 'Adūsı dileye her dem emānı

65 Vireler her ne deñlü istese māl Korup tek itmesün milkini pā-māl

66 Hudāyā eylegil fażluñla tevfīk Geçür taḳlīdden ḳıl ehl-i taḥ̂ịk

67 Hidāyet eyle sulțān-ı kerīme Kulag̉uzla ṣırāṭ-ı müstaḳime

68 Mübārek zāātına olsun du'ālar Devām-1 rif'ati içün senālar

\footnotetext{
${ }^{58} \mathrm{~B}$ nüshasında bu beyitteki mısraların yerleri değişiktir.

${ }^{60}$ hudūd-1:ḥudūda B

${ }^{67}$ kulagiuzla: ḳulavuzla B
} 
86 B 69 Hümāyūn devleti olsun muhalled

Muzaffer ola a'dāya mü'ebbed

70 Ola fermān-beri hep rub'-1 meskūn

Bula žāt-1 şerīifi ‘ömr-i efzūn

71 Hübūb itsün nesīm-i fetḥ ü nuṣret

Hem Allāhdan irişsün 'avn ü 'izzet

72 Du'ā-yı feth irişsün āsumāna

Șabā-yı naṣr girsün bād-bāna

73 Yemen yümn ile fetḥ olup kemā-kān

Muțī' ola cemi'i'-i ehl-i 'iṣyān

74 Müsülmānlar ṣıyup aṣhāb-1 ḳahrı

İçürsünler 'adūya āb-1 zehri

$117^{b} \mathrm{~T} 75$ Huarāb olsun ser-ā-ser mülk-i evbāş

K.ızıl ḳana boyansun hep ḳızlbaş

76 Yehūdā vü nasārīiden denīler

Fürū-māye 'aḳıl-ser-geştenīler

77 'Alef olsun olar şemşīr-i tīze İrişsün rāfıżi șadrına nīze

78 Dahıı Bag̉dādı fetḥ itsün cünūdı

Ḳralar cümle ol ḥumr-1 cühūdı

79 Gele dergāhına hayr-1 ḩaberler

İrişe şem'-i pākine hünerler

80 Anı ḳıl maẓhar-ı luṭ̂f-ı İlāhī

Hem olsun raḥmetüñ anuñ penāhı

\footnotetext{
${ }^{69}$ mü'ebbed:mü'eyyed B

${ }^{73}-\mathrm{T}$

${ }^{78}$ itsün:ide T
} 
81 Cemì'-i ehl-i ìmānuñ Huudāyā Haṭāsın sen gider luṭf it 'aṭāyā

82 İre mü'minlere raḥmet Hudādan Diyen āmīn emin olsun belādan

83 Bu sözlerle du'ādur aña maḳṣūd İde ‘ömrin ziyāde Hayy u Ma'būd

84 İlāhī vir reşādı Ḩān Murāda İki 'ālemde tā ire murāda

85 Geçür aḥvāl-i ḥaşruñ cümlesinden Kıll anı evliyāñuñ zümresinden

87ª B 86 Maḳām-ı aṣdıkāya irgür anı Müyesser ḳıl rı̇̇ā-yı cāvidānı

87 Anı aṣhạāb-1 aḥbāba ḳarīn it Ki ya'nì çār-yāra hem-nişīn it

88 İşitsün yā İlāhī ol hịțābuñ İrişdürme aña hergiz 'itābuñ

118 ${ }^{\text {a }}$ T 89 Tecellì-i cemālüñ ḳıl müyesser Degül bir kerre yā Rab bi'lmükerrer

90 Ne 'arż idem senüñ ma'lūmuñ olmaz Merātib kim buyurduñ ḳalbe gelmez

91 Kulaḳ işitmedi vü görmedi göz Tahayyül olmadı vü dimedi söz

92 Yaraḳladuñ anı șālih ḳul içün Naḳi vü mü'min ü muhlis-dil içün

93 Müyesser eyle yā Rab ol maḳāmı İrişe luṭf $u$ fażl aña tamāmī

\footnotetext{
${ }^{81}$ hațāsın:Hudāyā M (anlam gereği düzeltilmiştir.)

${ }^{89}$ bil:sil B

${ }^{92}$ naki vü:nakì-i B
} 
94 Dahı şol nesne kim fażluña lāyık

'Ațā ḳıl aña yoḳ luṭfuña ‘āyık

95 Recā senden ziyāde 'izzet eyle Kamu eslāfına sen raḥmet eyle

96 İlāhī cümlesine raḥmet eyle Kamusınuñ mekānın cennet eyle

97 Du'āmı işidüp kim dirse āmīn Muhașṣal eyle anuñ cümle kāmın

98 Sözüñ te'sīir ider olur du'ālar Eyü ḥaḳḳında çoḳ dürlü șenālar

99 Sözüñ İlmī senüñ nūr-1 cenāndur Delîl-i mūṣıl-1 hūr-1 cināndur

100 Mu'anber ḳıl cihānı müşg-bīz ol Mu'atțar it meşāmı 'ț̣r-rīz ol

101 Kelāmuñ ḳadrin irgür āsumāna Ola ḳandīl-i nūrāni cihāna

102 Oḳınduḳca mu'anber ola 'ālem Du'ā-yı hayr ideler şāha her dem

103 Dahıı her kim bu naẓm-ı dil-güşāya Naẓar ide elin açsun du'āya

87b B, 118 T 104 O sulțānı du'ā ile ide yād İde ol ḳulını Hạ ga gamdan āzād

105 Hudāyā bu du'āmı eyle maḳbūl Emīn olsun buña āmīn diyen ḳul

\footnotetext{
${ }^{96}-\mathrm{B}$

${ }^{103}$ dil-güşāya:dil kitāba B

${ }^{105}$ du'āmı: du'āyı B
} 
106 Du'āmuz bula bunuñla nihāyet Cihān halḳına yā Rab ḳıl hidāyet

107 Cemi'-i mü'minini eyle mes'ūd Ecib da'vātenā yā Șāhịibe'l-cūd

\section{SONUÇ}

Klâsik Türk edebiyatında pek çok konuda olduğu gibi dua konusunda da çok ve çeşitli malzemeyle karşılaşılmaktadır. Değişik nazım şekilleriyle yazılmış dua konulu münacaat, tazarruat, niyaznâme, istimdâdiye, tevbenâme, istiğfarnâme, ilticânâme gibi büyük küçük pek çok eser kaleme alınmıştır. Bunların her biri ayrı birer araştırma konusu olup elde edilen malzeme ölçüsünde tür olarak kabul edilebilecek konulardır. Duânâmeler de bu tür eserler arasında değerlendirilebilir. İlmî'nin bu eseri bunlardan sadece biridir. Bu nevi örnekler çoğaltılarak duânâme konusu başlı başına bir tür olarak incelenmeye muhtaçtır.

İlmî'nin bu eseri, kaside nazım şekliyle yazılmış klâsik cülûsiyyelerden farklı olarak mesnevî nazım şekliyle ve duânâme türünde yazılmış bir manzumedir. Bağdat ve Yemen'in feth edilmesi dileğinde bulunulması sebebiyle de bu eser, aynı zamanda bir fetih duası olarak da kabul edilebilir.

Eser, sosyal açıdan değerlendirildiğinde, Türk milletinin vatanına, devletine olan bağlılığını, kaybetme tehlikesiyle karşı karşıya kaldığı veya daha önce kaybettiği topraklara karşı olan hassasiyetini ortaya koyması bakımından son derece önemlidir. Zira bu eser, seferde asker olup orduya katılmanın yanı sıra katılamayanların da dualarıyla onlara iştirak ettiğini, manen onların yanında olduğunu anlatan güzel örneklerden biridir. 


\section{KAYNAKÇA:}

Akkuş, Metin (1993), Nef'̂̀ Divanı, Ankara: Akçă̆ Yay.

Akyüz, Kenan, Süheyl Beken, Sedit Yüksel ve Müjgân Cunbur (1958), Fuzûlî Divani, Ankara: Türkiye İş Bankası Yay.

Arat, Reşit Rahmeti (1986), Eski Türk Şiiri, Ankara: TTK Yay.

Aydemir, Yaşar (2000), Behiştî Dîvânı, Ankara: MEB Yay.

Bilkan, Ali Fuat (1997), Nâbî Dîvânt, 2 cilt, İstanbul: MEB Yay.

Bursalı Mehmed Tahir Efendi, Osmanlı Müellifleri, I, (haz. A. Fikri Yavuz ve İsmail Özen), İstanbul: Meral Yay.

Can, Mustafa (2001), 15-18. yy.larda Bazı Divanlarda Dua ve Beddua Beyitleri, Afyon: Afyon Kocatepe Üniversitesi, XII+143 s.

Ceylan, Ömür (2005), "Kadeh Duası ve Şerhine Dair", Böyle Buyurdu Sûfí: Tasavouf ve Şerh Edebiyatı Araştırmaları, İstanbul: Kapı Yay., 182-193.

Cilacı, Osman (1994), “Dua", DIA , 9, İstanbul: TDV Yay.

Çavuşoğlu, Semiramis (2001), "Kadızâdeliler", DİA, 24, İstanbul: TDV Yay.

Çelebioğlu, Âmil (1983), "Türk Edebiyatında Manzum Dinî Eserler", Şükrü Elçin Armağamı, Ankara.

Çelebioğlu, Âmil (1987), "Kültürümüzde Yatak Duaları", III. Milletlerarası Türk Folklor Kongresi Bildirileri, Ankara: KTB Folklor Araştırma Dairesi Yay., 95-102.

Dîvân-ı Vahŷ̂, Millet Kütüphanesi Ali Emîrî Ef. Böl. Manzum Eserler nr. 492. Halaçoğlu, Yusuf (1991), "Bağdat ( Osmanlı Dönemi)”, DİA, 4, İstanbul: TDV Yay.

Kâtib Çelebi, Fezleke, II, İstanbul, 1287.

Kâtib Çelebi, Mizânü'l-Hak fi İhtiyâri'l-Ahak (haz. O. Şaik Gökyay), İstanbul, 1972.

Kaya, Bayram Ali (2003), Azmî-zâde Hâletî Dîvânı, Harvard Üniversitesi Yakın Doğu Dilleri ve Medeniyetleri Bölümü, Türkçe Kaynaklar XLIX.

Mermer, Ahmet (1997), Karamanlı Aynî ve Dîvânı, Ankara: Akçağ Yay.

Nâimâ Tarihi, III.

Sabri, Şakir (1934), Gaziantep Büyükleri, Gaziantep: Halkevi Yay.

Saraç, M.A.Yekta (2002), Emrî Dîvânı, İstanbul: Eren Yay.

Sungur, Necati (1994), Âĥ̀ Dîvânı, Ankara: KB Yay.

Şeyhî Mehmed Efendi, Şakâik-i Numâniye ve Zeyilleri III: Vekâyiu'l-Fudalâ I, (haz. Abdülkadir Özcan), İstanbul, 1989.

Tarlan, Ali Nihad (1945), Hayâlî Bey Dîvânı, İstanbul: İÜ Yay. 
Tarlan, Ali Nihad (1963), Necatî Beg Divanı, İstanbul: MEB Yay.

Tezcan, Semih ve Hendrik Boeschoten (2001), Dede Korkut Oğuznâmeleri, İstanbul: Yapı Kredi Yay.

Ürekli, Bayram (1997), “Dördüncü Murad Devrine Dâir Kadızâde'nin Bir Manzûmesi", Selçuk Üniversitesi Fen-Edebiyat Fakültesi Dergisi, 11, 277300.

Yavuz, Kemal (1999), "Edebiyatımızda Gezen Nefesler", Tarih ve Medeniyet Dergisi, 61, 41.

Yılmaz, Mehmet (1992), Edebiyatımızda İslamî Kaynaklı Sözler, İstanbul: Enderun Kitabevi. 